\title{
Formal Rules and Informal Cooperation: Intergovernmental Relations in Domestic European Policy-Making in Comparative Perspective
}

\author{
Anna-Lena Högenauer \\ This is a pre-print version. For the original article, please consult \\ http://www.tandfonline.com/.
}

\begin{abstract}
One of the key elements of the strategies of interest representation of strong legislative regions in EU policy-making is active participation in the domestic co-ordination processes of the member state position. One could thus expect intergovernmental relations in multi-level states to be subject to a Europeanization process encouraging cooperation and leading to centralization. However, this paper argues that cooperation effects can only be confirmed for the formal rules on intergovernmental cooperation, which do generally require more cooperation than in domestic matters. However, when informal practices are taken into account, some member states become more cooperative, others arguably less. This divergence between cases can be explained by the intricate circular interplay of formal and informal practices. While the informal practices of actors mean that domestic coordination does not follow exactly the logic of formal rules, the incentives provided by formal rules shape what kind of informal practices emerge.
\end{abstract}


One of the key elements of the strategies of interest representation of strong legislative regions in EU policy-making is active participation in the domestic co-ordination processes of the member state position. One could thus expect intergovernmental relations in multi-level states to be subject to a Europeanization process encouraging cooperation and leading to centralization. However, this paper argues that cooperation effects can only be confirmed for the formal rules on intergovernmental cooperation, which do indeed require more cooperation than in domestic matters. However, when informal practices are taken into account, some member states become more cooperative, others arguably less. Also, while centralization effects are manifest in most cases, some regions manage to circumvent these by means of informal coordination. This divergence between cases can be explained by the intricate interplay of formal and informal practices. On the one hand, the informal practices of actors mean that domestic coordination does not follow exactly the logic of formal rules. On the other hand, the incentives provided by formal rules shape what kind of informal practices emerge. 


\section{Introduction}

Differences in regional participation in European policy-making start at home. Both scholars and policy-makers are acutely aware of the difficulties of developing theories or European level mechanisms of participation that fit regions of centralized and regions of federal states alike. It is striking, though, just how diverse the formal mechanisms for domestic European policy-making are for even the strongest legislative regions.

One of the key elements of the strategies of interest representation of strong legislative regions in EU policy-making is active participation in the domestic co-ordination processes of the member state position (Jeffery, 2000). In federal and quasi-federal member states, regional governments are usually entitled to some involvement in the formulation of the member state position in EU matters. However, the formal rules governing this coordination process differ between member states.

While the formal rules (e.g. constitutional or legal rules on the use of certain institutions, majorities etc.) are fought over in practice, both academics and practitioners alike acknowledge the existence of an elaborate system of informal practices (i.e. all practices that are not required by law) in the domestic coordination of EU matters (Kovziridze, 2002). In fact, these informal practices are often described as eclipsing formal rules, both in quantitative terms (i.e. how much of the coordination process is governed by formal practices in relation to informal practices) and in qualitative terms (i.e. where agreement is reached) (ibid.; Beyers \& Bursens, 2006: 1067) and in many cases they become highly institutionalized (i.e. take place in a certain pattern on a regular basis). 
The objective of this article is to return to the domestic coordination processes on EU affairs of federal and quasi-federal states with a view to not only understanding the different forms of coordination in practice, but also to understand the relationship between formal rules and informal practices and their interplay with Europeanization. In particular, this article will examine the hypotheses of the theoretical framework of this special issue that Europeanization leads to greater centralization and more cooperative practices in multi-level states (cf. hypotheses 3 and 4 of the introductory article). However, it further argues that there is a difference between the Europeanization of formal rules and Europeanization of the system as a whole, including informal practices. It argues that the literature underestimates the importance of formal rules, because they are often only used to formalize, i.e. "rubber-stamp", informal compromises in day-today policy-making. The importance of formal rules lies elsewhere, namely in the provision of system-shaping incentives and disincentives for certain types of action. Thus, the hypothesis is that the extent to which cooperation takes place in practice depends on the weight attributed by formal rules to the collective positions of the regions vis-à-vis the position of the central state.

The hypothesis will be tested in the case of EU water policy, in particular the Bathing Water Directive of 2006. The empirical data will be complemented, where appropriate, with insights from the similar case of the Flood Risk Management Directive of 2007. The focus thus lies on regulatory policy-making - the most common type of EU policymaking. The country cases comprise Belgium and Scotland as examples of dual systems and Germany and Austria as examples of cooperative systems. The cases were reconstructed through process-tracing on the basis of qualitative semi-structured 
interviews and documentary analysis of policy papers, press releases, newsletters etc (cf. next section).

The following sections will first discuss the theoretical framework and research questions. The second section will focus on formal, written rules, arguing that in Europeanization has indeed a cooperation and centralization effect on formal rules. However, the analysis of informal practices in the third section shows that - in some cases - the actual coordination of the national position follows a different logic from the system set out in the formal rules due to the quantity and nature of the informal practices in that member state. The fourth section explains this variation between member states in informal practices with reference to the incentives and disincentives for cooperation provided by their respective sets of formal rules.

\section{Europeanization and Multi-Level States}

Europeanisation is a popular concept that has been applied to a wide variety of aspects of European integration, such as the construction of European institutions, the capacity of member states to shape European policies and adapt to European policies and how European opportunities and constraints affect national politics. It overlaps with the multilevel governance literature where the Europeanisation of federal structures, regional actors or policies with regional input is concerned (e.g. Conzelmann 1998; Benz and Eberlein 1999; Bache 2007; Beyers and Bursens 2006). This article employs a circular definition of Europeanization as "a shorthand term for a complex process whereby national and subnational institutions, political actors, and citizens adapt to and seek to 
shape, the trajectory of European integration in general and EU policies in particular" (Bomberg and Peterson 2000: 7). This definition captures the idea that domestic actors adapt to European developments in order to be able to influence (future) European developments (cf. Börzel and Risse 2000: 1; Radaelli and Pasquier 2007).

One of the advantages of the Europeanization literature is that it focuses more on the interplay between subnational and national actors in EU policy-making than the multilevel governance literature, which acknowledges this interplay but generally concentrates on the direct link between subnational and supranational actors. Studies of the transformation of the Belgian federal state and Flemish strategies in EU policy-making (Bursens and Deforche 2008; Beyers and Bursens 2006; Kerremans and Beyers 1997), for example, suggest that European integration created the need to find a common Belgian position in European negotiations and thus put the dual structure of the Belgian state under pressure. As a result, it gave rise to increasingly cooperative practices amongst domestic actors that normally try to avoid cooperation (cf. Beyers and Bursens 2006). In the German case, by contrast, Knodt argues that the German Länder increasingly adopt individualistic strategies of interest representation in European policymaking rather than working through the Bundesrat and the CoR (Knodt 2000: 239-40). These two examples already point towards the diverse impact of Europeanization even between federal states.

The motivation to adapt to European developments can be explained with reference to the concepts of "fit" and "misfit". Several studies show that Europeanisation does not automatically lead to convergence, as a number of domestic factors shape the impact of EU pressures (Ladrech 1994; Risse, Cowles and Caporaso 2001). This has led to a 
creation of typologies of member states, which is, however, disputed. According to Caporaso $(2007,29)$ the institutional 'fit' between federal states and the EU is greater than for unitary states, as the EU reflects the territorial structures of federalism better than the centralised policy-making systems of unitary states. Bache uses a similar typology informed by Schmidt's distinction of compound systems (proportional representation system, corporatist policy-making processes and regionalized or federalized structures) and simple polities (majoritarian representation, statist policy-making, unitary state structure) (Schmidt 2006: 227). He argues that European cohesion policy will fit compound polities better than simple ones, but admits that some states do not conform to the typology (Germany) and that there are also variations between different regions within member states (Bache 2008: 63-5, 70, 154). By contrast, Börzel (1999, 577-8) argues that the regions of federal/regionalised states lose power due to European integration, which suggests that there is a misfit between federal systems and the pressures of European integration. She also breaks down the apparently homogeneous group of federal and regionalized states into two subgroups attributing to the cooperative/competitive political cultures an impact on the choice of strategy of regional interest representation.

In line with the introduction to this special issue, this article argues that there is a misfit of structures between multi-level states and European integration (cf. Introductory article). Successive rounds of enlargement to more centralized states have increasingly marginalized multi-level states, while attempts to provide institutions of formal representation at the European level, such as the Committee of the Regions, were unsuccessful. Participation in the coordination of the national position is still one of the 
most important channels of influence. However, formal rules on regional participation in the formulation of national positions vary between member states. This raises a number of questions: What is the impact of Europeanization on domestic inter-governmental coordination and to what extent does it differ between member states? What is the role of formal rules on intergovernmental cooperation in shaping the outcome of Europeanization (if any)?

As regional governments still lack formal powers individually at the European level, the expectation is that they will try to exercise formal powers through the national position and thus the central state. In order to do that, they need to coordinate with other actors within the member state. Thus, following the theoretical framework of this special issue, the first hypothesis is thus that Europeanization leads to greater centralization and more cooperative practices in multi-level states. This impact is likely to be more noticeable in the case of dual or competitive multi-level systems, due to their different starting point. (cf. hypotheses 3 and 4 of the introductory article). Federalism or decentralization that follows the 'dual' model is characterized by an attempt to constitutionally separate policy-making powers between different levels by allocating the actors exclusive competences as far as possible. By contrast, 'cooperative' systems are characterized by shared competences between the centre and the regions and thus joint decision-making and/or situations where one level implements the decisions of another level.

In addition, formal rules on intergovernmental coordination are expected to act as an intervening variable. The hypothesis is that some sets of rules provide regions with more control of the national position than others, so that the incentives to cooperate with the central government and/or other regions are stronger in some member states than in 
others. Therefore, the second hypothesis is that the extent to which cooperative practices develop depends on the weight attributed by formal rules to the positions of the regions and on barriers (e.g. consensus requirements) to cooperation.

Formal rules will refer to all legal or constitutional requirements governing intergovernmental cooperation in EU affairs, whereas informal practices refer to all other activities and institutions that are not prescribed by law. Formal and institutionalized should not be confused. The degree of institutionalization refers to the extent to which something has become a well-established, regular practice. Practices governed by formal rules will usually be highly institutionalized because they are required to take place (e.g. the formulation of a Bundesrat position in Germany). However, informal practices are not necessarily ad hoc. They can be ad hoc, such as spontaneous phone calls to request feedback or information, but they can also become highly institutionalized if they are seen to work well. For example, the discussion of EU affairs at interministerial conferences in Germany is not a formal requirement, but it has become a highly institutionalized practice.

Empirically, these hypotheses will be tested against the cases of Germany, Austria, Belgium and coordination between the UK and Scotland in the case of Directive 2006/7/EC concerning the management of bathing water quality (hereafter: Bathing Water Directive). The four country cases were selected on the basis that they represent a set of two cooperative systems (Germany and Austria) and two dual systems (Belgium and the UK). Data was collected on seven regions (Scotland, Carinthia, Vorarlberg, Mecklenburg West-Pomerania, Bavaria, Wallonia and Flanders) that were all affected by the policy problems and thus had a reason to mobilize. The role of the policy in the 
research was to provide a means to reconstruct concrete processes of coordination and to avoid relying on vague claims about "frequent" or "rare" interactions with this or that actor. A series of qualitative interviews and documentary analysis were used to reconstruct the process of coordination of the national positions. In some cases, interviews in relation to the Flood Risk Management Directive will be included to corroborate the analysis. Generally, the process of negotiation of that Directive was very similar, but could not be included here for reasons of space. Interviews on flood risk management will be indicated with as 'Interview F ...'

The logic behind the choice of the Bathing Water Directive was to find a "good case" that would affect all case study regions and thus lead to interest and mobilization in the regional government and that would be fairly representative of "normal" domestic coordination. As the Bathing Water Directive does not involve direct funding or raise issues of sovereignty (Bathing Water had already been regulated in an old Directive), it is not an exceptional "ideal" case. But what makes it a representative "good" case is that it nevertheless affects the regions in their legislative powers. ${ }^{1}$ In addition, all regions are affected by the policy problem: all have a number of bathing waters. In all cases, the media reported on the quality of national bathing water with reference to the European legislative framework. In all cases bathing water was salient for reasons of tourism and/or due to extensive problems and media reports. Finally, during the negotiations the inclusion of all water sport (e.g. surfing or kayaking) was considered, which led to considerable protests, as this could have led to a restriction of the exercise of water sport during certain months (cf. for a detailed discussion). 


\section{Formal Coordination: Differing Frameworks for Regional Involvement across Member States}

All multi-level member states recognize the right of their regions to be involved in the coordination of the national position on EU affairs. However, the precise modalities of regional involvement differ hugely across member states, as formal rules are in line with the organizational logic of the member state (i.e. the dual or cooperative nature of the federal state) and reflect the strength of the region in domestic policy-making more generally (i.e. whether regions have a large number of exclusive competences, how strong they are in areas of shared competences and where sovereignty is seen to lie). Based on the hypotheses, two dimensions are particularly important for the analysis of formal rules on domestic cooperation on EU affairs: the extent to which regions are required or encouraged to cooperate with the other regions of the member state (horizontal cooperation) and the degree of influence they have over the member state position. It should be noted that both dimensions are evaluated purely with regard to the formal rules here. The cases of Germany, Austria, Belgium and the UK illustrate the diverse logics at work (cf. Figure 1 here).

\section{Figure 1 here}

In Germany, the formal mechanisms of coordination in European matters are laid down in Art. 23 of the Basic Law (BL) and the Law on Cooperation (LC) between the Bund and the Länder Concerning European Matters of 12 March 1993. The coordination takes 
place between the federal government and the collective position of the Länder as expressed in the Bundesrat through a majority vote. As a result, individual Länder governments do not enjoy equal status to the federal government in the process (Kovziridze, 2002: 140), as the Länder are only empowered collectively.

If the European measure predominantly concerns the legislative and administrative competences of the Länder, the position of the Bundesrat has to be decisively taken into account ("massgeblich zu berücksichtigen") without prejudicing the federal responsibility for the Republic. This was the case for the Bathing Water Directive, where three positions were adopted. For legislative projects that touch upon predominantly federal competences, the Bundesrat position merely has to be taken into account. The same applies if the project affects concurrent federal-regional competences when the federal government has already previously legislated in the area (see Kovziridze, 2002; MüllerGraff, 2005; Art.23 BL and §5(2) LC). On the whole, the level of influence of the German Laender according to the formal rules is high when their competences are predominantly concerned - as in the case of bathing water - but consultative when they are not.

In Austria, the Länder can also only exercise influence collectively. In cases of European legislation that affects their exclusive competences, the Länder can adopt a 'unified position' that binds the federal government except if there are compelling reasons of integration or foreign policy that require adaptation (see Art. 23d of the federal constitution and the Vereinbarung zwischen dem Bund und den Ländern gemäss Art. 15a B-VG über die Mitwirkungsrechte der Länder und Gemeinden in Angelegenheiten der europäischen Integration, 1992). As the definition of this exception is rather vague, the 
federal government has some leeway in practice. Unified positions have to be adopted by a majority of Länder (at least five) with no opposition from the remaining Länder. According to the Vereinbarung zwischen den Ländern gemäß Art. 15 a B-VG über die gemeinsame Willensbildung der Länder in Angelegenheiten der europäischen Integration, the Integration Conference of the Länder, consisting of the Landeshauptmänner and the Presidents of the parliaments of the Länder, is responsible for the horizontal coordination. In reality, there is considerable flexibility in the interpretation of these rules and the Integration Conference only plays a minor role as the unified position of the Länder tends to be elaborated by the Landeshauptleutekonferenz or the experts of the Länder (Bussjaeger \& Djanani, 2009: 60).

As the Austrian Länder have only few exclusive competences, only 75 unified positions were adopted between 1993 and 2008, an average of about five a year (Bussjaeger, Bär, \& Willi, 2006: 61; Bussjaeger \& Djanani, 2009: 42, 75). In all other policy areas including the case of bathing water - the Länder can adopt 'simple positions' individually or coordinate horizontally to achieve a common position. A number of simple positions were adopted by various Länder including the two case study regions on the Bathing Water Directive. These positions are, however, non-binding. Overall, the Austrian Länder thus have a weak position in the internal coordination mechanisms for European policymaking due to the obligation for consensual agreement (Morass, 1997: 81-2) and the limited number of exclusive regional competences where binding positions can be reached.

Because of their domestic strength, the Belgian regions have obtained the status of "veto players" and enjoy by far the highest level of influence over the coordination of the 
national position (Lambertz \& Foerster, 2009: 24). The central coordinating role for Belgium's official position in the European Union is played by the Directorate for European Affairs of the Federal Public Service of Foreign Affairs (DEA). It is an administrative body composed of representatives of the federal, regional and community ministries and headed by a federal representative. Decisions are taken by consensus, which confers an equal status on the regions, communities and the central government (Kerremans \& Beyers, 1997: 50). The federal level can at best achieve a slight degree of primacy through the use of its monitoring and coordinating role (Kovziridze, 2002: 138). This is also the procedure used for the Bathing Water Directive.

In the absence of consensus, ministers from the different levels will discuss the issue in the Interministerial Conference for Foreign Policy. If no common position can be found, the Prime Minister and regional and community minister-presidents will meet in the Consultation Committee. In practice, the DEA reaches agreement on the vast majority of issues (138).

In the UK, despite a high level of devolution with regard to domestic policy-making, the negotiation of EU legislation is a "reserved matter" under the 1998 Scotland Act. The central government is thus only obliged to consult the devolved governments and remains firmly at the heart of the process. In addition, intergovernmental relations for the purpose of defining Britain's position on EU policies have generally been characterised by a much lower degree of formalisation than in the other three member states (Cairney, 2006: 439).

Intergovernmental relations between Scotland and the UK are governed by a Memorandum of Understanding (MoU) and a series of concordats on specific 
mechanisms or policy areas, such as the Concordat on the Coordination of European Union Policy Issues and the Concordat between the Department of Environment, Transport and the Regions and the Scottish government. These Concordats are nonbinding agreements between the UK government and devolved governments and support administrative practices (Lynch, 2001: 150). Labour governments both at the centre and in Scotland initially further reduced the need for formal mechanisms, as Labour felt compelled to make the policy of devolution work and as intra-party politics could resolve many issues (Laffin, Shaw, \& Taylor, 2007; Swenden, 2009). On the whole, the absence of formal and binding rules results in the devolved governments having no "hard" powers in domestic EU policy-making.

The main mechanism of internal conflict resolution specified in the MoU and the Concordats are Joint Ministerial Committees (JMC), which can be used to coordinate both devolved and non-devolved matters. Meeting about two to four times a year, the JMC on European affairs has played some role in the discussion of the UK's broad strategy on European matters (MacPhail, 2008: 21). In the absence of formal channels other than the JMC, the coordination of the Bathing Water Directive took in practice place through informal channels (see below).

Overall, those member states that have divided competences according to a dual model have also opted for a model of domestic European policy-making where each region is being consulted individually, which limits the level of horizontal cooperation but still implies a degree of centralization and somewhat more cooperation than in purely domestic policy-making. Those states that follow a model of cooperative federalism have 
again adopted a model of coordination where the regions have collective influence and that mirrors the practices in place in domestic policy-making more generally.

\section{Cooperative Trends through Informal Practices?}

The formal rules on intergovernmental coordination of national positions tell only part of the story, as they are complemented and, arguably, eclipsed by a dense net of informal practices and institutions in every day policy-making. In some cases, such as the United Kingdom, the prevalence of informal practices is unsurprising, as formal rules are vague. But even in Belgium and Germany, where the rules on coordination are clear, coordination is largely achieved through informal exchanges. As the precise nature of informal arrangements varies somewhat from policy area to policy area, the informal mechanisms are, in the following, illustrated through the examples of EU bathing water policy. The case affected the regions in their implementation powers and legislative powers, with the exception of the Austrian Länder (which have few legislative powers). It is argued that informal practices modify the cooperation and centralization effect of Europeanization.

\section{Germany: The Collective Reflex}

In Germany, in the early stages of the negotiation of the Bathing Water Directive, the Bundesrat adopted three Decisions on bathing water and decided on the common representative in the German delegations to Commission and Council working groups (Bundesrat, Press Release No. 19/2002, 1/02/2002; Bundesrat, Beschluss No. 49/02, 
1/02/2002; Bundesrat, Beschluss No. 857/02, 14/02/2003). Normally, internal agreement on this question is in practice reached at the level of secretaries of state and ministers, before it is formalised in the Bundesrat (Interview $\mathrm{F}$ representative of the Bundesrat 7/04/2009), but for the Bathing Water Directive, an official from Schleswig-Holstein had acted as representative of the Bundesrat since 1992 or 1993, when he witnessed the failure of the first attempt to revise the old Directive (Interview Representative of the Bundesrat 24/04/2009). Also, most of the coordination on the policy de facto took place in informal but highly institutionalised arrangements. Thus, the Umweltministerkonferenz (Conference of the Ministers of the Environment) is used to reach political agreement on the highest political level. Despite its lack of formal status, it has reached a high degree of institutionalisation in domestic policy-making and is supported by an array of committees that help to prepare agreements before Bundesrat proceedings and react to European developments (www.umweltministerkonferenz.de; cf. Palmer 2004: 57).

The day-to-day substantive coordination took place within the Bund-Länder working group on bathing water (BLAK-bathing water), which met two to three times a year and was attended by Länder experts and chaired by the representative of the Bundesrat (Interviews official (2) Bavarian Ministry of the Environment and Health 4/03/2009; official (1) Federal Ministry of the Environment 20/03/2009; official (2), Federal Ministry of the Environment 20/03/2009; Interview Representative of the Bundesrat 24/04/2009). It reported to the LAWA (Länder Arbeitsgemeinschaft Wasser - Länder Working Group on Water), which consists of the Heads of Departments of the highest Länder administrations for water management. The LAWA meets twice a year before the meetings of the Conference of Heads of Departments (ACK) and the Conference of 
Ministers of the Environment (UMK), to which it reports (www.umweltministerkonferenz.de/Arbeitsgremien.html, www. lawa.de).

In addition, there were frequent email exchanges, usually initiated by the federal expert responsible for the German position in the EU. During these exchanges, the Länder had the opportunity to react to developments in Brussels and raise concerns (Interview official (1) Federal Ministry of the Environment 20/03/2009).

At the transposition and implementation stage, the same mechanisms prevailed as at the negotiation stage. Thus, the task of transposing the Bathing Water Directive was addressed collectively in working groups that created, for example, a blueprint document for the transposition, a document on information policy and a recommendation on how to tackle the bathing water profiles (Interviews official (2) Bavarian Ministry of the Environment and Health 4/03/2009; official, Ministry of Social Affairs of MecklenburgWest Pomerania, 18/03/2009).

On the whole, the informal practices support the collective approach of the formal coordination processes. With a tradition of decade-long cooperation in the field of water policy, the Länder voluntarily exchange information and coordinate. In this case, Europeanization confirms preexisting cooperative tendencies.

\section{Austria: Collective or Bilateral Coordination?}

The Austrian Länder have only limited competences in the area of water policy. As a result, the Austrian Länder could at best pass a consultative common position, which they did not do. Instead they relied on individual positions alone. This is not unusual. When no 
binding unified position can be passed, the Laender often avoid the effort of agreeing on a joint position (Interviews official, Amt der Vorarlberger Landesregierung 26/03/2009; official, Liaison Office of the Austrian Länder 2/04/2009).

In the case of the Bathing Water Directive, there was thus a juxtaposition of bilateral and collective elements. The two main coordination instruments between regions and between regions and the federal level were the Liaison Office of the Austrian Länder and the common representative of the Länder. The Liaison Office of the Austrian Länder was mainly involved as a hub for information exchange between regions and between the federal level and regions and as a coordinator of the nomination process for the common representative of the Länder (Interviews Federal Ministry of Health 3/04/2009; official, Liaison Office of the Austrian Länder 2/04/2009; F official, Amt der Kärntener Landesregierung Abt. 18 30/03/2009, also Vereinbarung zwischen dem Bund und den Ländern gemäß Art. 15a B-VG über die Mitwirkungsrechte der Länder und Gemeinden in Angelegenheiten der europäischen Integration). In the absence of a common position, the Liaison Office circulates position papers from individual regions for comment by other regions (Interview 1). However, the other Länder often do not react to individual positions (Interviews official, Amt der Vorarlberger Landesregierung 26/03/2009; official, Liaison Office of the Austrian Länder 2/04/2009; also F official, Amt der Kärntener Landesregierung Abt. 18 30/03/2009). The absence of a unified or common position thus weakens the collective reflexes of the coordination system.

In addition, Länder sometimes send their positions directly to the lead ministry. In that case, the positions may not get circulated to the other Länder. Thus, the Austrian national expert on bathing water recalled initially receiving positions from all Länder, but the 
interviewee from Vorarlberg only found a few Länder positions on file (Interviews official, Amt der Vorarlberger Landesregierung 26/03/2009; official, Liaison Office of the Austrian Länder 2/04/2009, ).

The second main task of the Liaison Office is to coordinate the nomination process of the common representatives of the Länder (Interviews official, Liaison Office of the Austrian Länder 2/04/2009; 12, also F official, Amt der Kärntener Landesregierung Abt. 18 30/03/2009; official, Federal Ministry of Health 3/04/2009). Once the Länder agreed upon a common representative, she took over the coordination process during the negotiation, transposition and implementation of the Directive and represented the Laender vis-à-vis the federal ministry. However, as the preparatory meetings of the Federal Ministry of the Environment for upcoming Council meetings cover a variety of issues, Länder experts with their focus on specific dossiers are usually not invited. The role of the Liaison Office is then to represent and inform the Länder (Interview Liaison Office, 2/04/2009).

Overall, the case of the Bathing Water Directive relied greatly on the coordination through the common representative and Liaison Office. Unlike in Germany, there were no regular working groups at the negotiation stage or at the implementation stage (Interviews Austrian Federal Ministry of Health, 3/04/2009; F Amt der Kärntener Landesregierung, Abteilung 18, 30/03/2009; Amt der Kärntener Landesregierung, Abteilung 15, 30/03/2009). At the implementation stage, the federal level prepared the transposition and then presented the drafts to the Länder for comments (Interviews Austrian Federal Ministry of Health, 3/04/2009; ). 
Overall, when the Austrian Länder adopt a unified or common position, the Austrian logic of coordination is similar to the German one. There are two steps, coordination between Länder and negotiation between the Länder and the federal government and there is a common representative who represents the Länder position vis-à-vis the federal government. However, when the Länder do not have the option of a binding unified position, they often do not agree a formal common position at all. In that case, especially during the important early stages, the coordination process consists of bilateral consultation. The result is a further increase in the power of the center and a decrease in the level of cooperation.

\section{Belgium: Competition and Cooperation}

The coordination of the Belgian position on the Bathing Water Directive took place mostly on the regional level, with Flanders and Wallonia being particularly active for reasons of policy salience. The level of cooperation between the regions prior to the European plans for the Directive was very limited and contacts between experts were rare, despite the fact that an 'old' Directive was already in place (Interviews DGARNE 20/05/2009; VMM 8/06/2009; F VMM, 18/05/2009).

Since its Council presidency in 2001, Belgium has coordinated its position on environmental matters through "pilots". Pilots are a regional or federal expert in charge of coordinating the Belgian position on a specific dossier (De Baere 2004). As the Bathing Water Directive fell into exclusive regional competences, the pilot was a regional expert from Flanders. Pilots are identified in the CCIM, the Cooperation 
Committee for International Environmental Policies, which is chaired by the national minister and attended by the three regional ministers and heads of administration in the case of exclusive regional competences (CCPIE Groupe Directeur Eau, 23/03/2009). The decision on the pilots is reached by consensus (Interview Belgian Permanent Representation 27/05/2009).

According to the interviewees, the Belgian position on the Directive was virtually exclusively agreed between the regions, as the national level had no competences (Interviews DGARNE 20/05/2009; VMM 8/06/2009; Belgian Permanent Representation 27/05/2009). Coordination between regions was mostly done via email and in meetings, with most meetings taking place in Brussels before Council working group or Commission committee meetings (ibid.). Once the pilot had elaborated a compromise, it was formalised in the DEA (Directorate for European Affairs). A similar situation arose in the case of the Flood Risk Management Directive (Interview F VMM, 18/05/2009). Similarly, Deforche and Bursens found that in cases that fell into exclusive regional competence, such as agricultural policy, the coordination was mainly interregional and started at the level of officials (2006: 35)

At the implementation stage, cooperation between regions was nearly exclusively limited to European committees and working groups. There were at best one or two meetings of the regions on legal matters, but nothing systematic. There was no intention to harmonise transposition and implementation in Belgium, other than for those parts that had to be coordinated due to EU reporting requirements (Ibid.).

On the whole, the informal process of coordination confirms the strength of the Belgian regions in domestic European policy-making in policy areas that fall under their 
exclusive competences. The formal coordination in the DEA confers equal importance upon each government, regional or federal, through the consensus requirement. However, just as in the case of the German Bundesrat, the formal mechanisms often only serve to formalise agreements that have already been reached. Thus, in the case of the Bathing Water Directive, the substantive coordination at that level generally involved regional experts only. As a result, the federal level played a minor role in the formulation of the Belgian position. One could thus argue that the regions are even more influential because of the informal mechanisms than they are in the official ones, as they can effectively relegate the federal level to the role of arbiter.

While the regions remained in control, they were also forced to cooperate closely with one another, confirming the hypothesis and previous research by Beyers and Bursens (2006). At the same time, there was little cooperation between the Belgian regions before the European initiative or outside international fora, despite 25 years of European legislation on bathing water. Similarly, the low level of coordination for implementation and transposition purposes confirms that cooperation is motivated by necessity and not a change in attitudes.

\section{UK}

In the UK, while the MoU only foresees the JMCs as co-ordination mechanisms, they are not the principal means of coordination. On the political level, concrete coordination on European legislative projects mainly happens through ministerial write-arounds before major events that provide the relevant devolved ministers with updates and allow the devolved executives to state their views. Even in the case of conflict, coordination via 
phone or bilateral meetings between ministers are the norm (Cairney, 2006; Lynch, 2001: $151-3)$.

In the case of the Bathing Water Directive, the Scottish administration received information on EU developments from DEFRA, drafted the Scottish position and sent it on to DEFRA (Interviews Water, Air, Soils and Flooding Division of the Scottish Government 6/05/2009; SEPA, 7/08/2009). On the political level, there were writearounds before every major Council meeting (Interview former official of DEFRA, 7/07/2009). Most of the internal coordination took place at the administrative level through a mixture of phone calls, emails, meetings and video-conferences. A policy lead group met between once and three times a year, depending on the phase of the negotiations (Interviews Water, Air, Soils and Flooding Division of the Scottish Government 6/05/2009; SEPA, 7/08/2009; cf. Högenauer 2012: 202-6; Carter and McLeod 2005: 72).

The Bathing Water Directive was transposed separately by Scotland under its devolved powers. There was no formal coordination between transposition laws in different parts of the UK to the extent that it takes place in Germany or Austria. However, there were regular meetings between all four administrations, about three to four times a year, for the purpose of information exchange (Interviews former official of the Water, Air, Soils and Flooding Division of the Scottish Government, 24/06/2009; Water, Air, Soils and Flooding Division of the Scottish Government 6/05/2009; former official of DEFRA, 7/07/2009).

Overall, the exchanges were often ad hoc and rarely took place in regular working groups. Also, the devolved administrations did not coordinate their positions prior to 
negotiations with the central departments. In the absence of a joint representative or a common position, the UK thus experiences the lowest cooperation effect, which further strengthens the role of the central state.

The literature on Scotland's engagement in European policy-making explains the bilateral nature of intergovernmental relations by pointing towards three factors (Swenden, 2009: 222; Trench, 2008: 106). First of all, the uneven nature of devolution means that the devolved governments are often affected to different degrees. Secondly, the fact that the UK government still represents England means that even a common position of the three devolved governments would only represent about 15 percent of the population (Hazell, 2000: 269-71). Finally, a lack of common borders means that cooperation between Wales, Scotland and Northern Ireland is unlikely to be triggered by cross-border issues.

Reports on how well this informal system of coordination works differ. Bulmer et al argue that the devolved administrations have become relatively powerful players (Bulmer, Burch, Hogwood, \& Scott, 2006). Yet, the leaked Aron report highlights problems such as the flow of information and the level of access to European actors granted to Scottish officials, which highlight the relative powerlessness of Scotland (Aron 2006). Also Reid and Ruiz-Rico Ruiz emphasise the subordination of the Scottish government to the UK government in EU affairs (Reid \& Ruiz-Rico Ruiz, 2003). According to them, the amount of EU legislation in environmental affairs combined with the low level of Scottish influence over the UK position even risks undermining the devolution settlement (223).

\section{The Bigger Picture: Formal Rights Matter}


The empirical analysis of the four cases shows three things. Firstly, the formal rules on domestic European policy-making all either match the usual cooperative tendencies of the member states or increase them. As the EU requires member states to present a single national position and as all federal and quasi-federal states allow their regional governments to participate in the formulation of the national position, the different actors are necessarily brought together. In general, the formal rules mirror the situation in domestic policy-making: cooperative federal states empower their regions collectively and encourage them to adopt joint positions (Germany, Austria); dual states empower their regions individually with consultation (UK) or veto rights (Belgium). Especially, in the case of dual states, this represents an increase in cooperation compared to domestic policy-making The coordination hypothesis is thus confirmed.

Secondly, in all member states, this goes hand in hand with the strengthening of the central executive. In Belgium, the central government is represented in fora that debate policies that fall under exclusive regional competences. In Germany and Austria, the regions can only adopt binding positions if the policy area is either exclusively or primarily their competence, and even then the national government can avoid compliance under certain conditions. In the UK, the devolved executives have only consultative rights even in policy areas that otherwise fall under their exclusive competence. The centralization hypothesis is thus also confirmed.

However, while an analysis of the formal mechanisms of coordination thus suggests that Europeanization leads to convergence around cooperation and centralization, the picture becomes more nuanced once we focus on horizontal cooperation between regions and once the actual informal and often highly institutionalized practices of actors are taken 
into account. Thus, in Belgium and Germany horizontal cooperation is high, whereas in the UK and - in many cases - in Austria it is low. This finding is intriguing as it transcends the dual-cooperative divide. There are also differences between Belgium, where horizontal cooperation is high but only during the decision-making phase, and Germany, where it is more sustained. Finally, in practice, the centralization effect seems to be minimal in Belgium, as the national position is de facto agreed between affected regions. Thus, the logic of formal mechanisms is in some cases changed by informal practices. In Germany, informal horizontal cooperation supports formal rules on cooperation and in the UK no horizontal cooperation is required and none happens. But in Belgium the central government loses influence due to informal practices and in Austria horizontal cooperation is often limited, whereas the formal rules foresee coordination between the central government and the regions collectively. Europeanization thus turns the dual/cooperative logic on its head in the case of Austria and Belgium (cf. Figure 2).

\section{Figure 2 here}

Thus, the third finding is that the pattern of differences between the countries suggests that what kind of informal processes emerge is shaped by the underlying incentive structure provided by formal rules. As stipulated by the second hypothesis, incentives and barriers are particularly relevant, i.e. the extent to which the collective or individual regional position(s) can influence the national position as a whole and factors that impede collective influence. 
The formal provisions for the coordination of the German national position state that the regions agree on a collective position in the Bundesrat which then has to be taken into account by the federal government. When the Länder competences are affected in important ways, the procedure thus means that the Länder position is collective and influential. The barriers to reaching a collective position are low in that majority voting can be used. In the absence of further informal arrangements, this procedure would produce relatively rigid outcomes and most likely lead to internal conflict, as it does not foresee a genuine mechanism of negotiation between the federal government and the Länder. As a result, an array of informal but well-established practices have evolved that include both Länder officials and federal experts and that allow the different levels to take the other's position in to account at an early stage. It also facilitates the search for a solution that is viable for all Länder.

In spite of similarities at first sight, the formal provisions create different incentives in Austria. In areas of exclusive regional competence, the Austrian system also foresees a collective regional position which has considerable influence over the national position (Kovziridze, 2002: 147). Here, the basic dynamics are very similar to the German system. However, there are only few exclusively regional competences and thus in the vast majority of cases even a unified Länder position would only be consultative. In those cases, the Länder have no incentive to undergo the additional effort of reaching a common position. In addition, consensus between nine Länder constitutes a high barrier to the formulation of a joint position. As a result, the option of a unified position is rarely used. The Belgian system gives regions a large amount of influence over the national position by giving them a veto right in areas of exclusive regional competence. While this 
may appear to give individual positions great influence, it ultimately emphasizes collective decision-making (Beyers, Delreux, \& Steensens, 2004). The consensus requirement effectively gives each actor "ownership" of the position. Lack of agreement due to poor coordination would lead to a Belgian abstention in the Council, i.e. a near complete loss of influence on the part of all Belgian actors. Thus, in order to be effective, the formal mechanisms require preparation thorough horizontal coordination. The fact that there are only three regions means that consensus represents less of a challenge than in Austria. At the same time, the fact that this cooperation does not even spill over to the implementation stage of a policy shows that it is motivated by necessity rather than a change in attitudes.

Finally, in the UK, domestic European policy-making is dominated by vertical bilateral relationships. Both formally and informally the system strongly relies on providing the devolved executives with the necessary information and collecting their reactions. The central government is not obliged to incorporate these positions. As a collective position of the devolved governments would still represent only a small minority of the populationof the member state, it would only carry little more weight than individual positions.

Thus, overall, regions tend to make the effort to coordinate their position with other regions if their influence under formal provisions is to some extent contingent upon successful inter-regional cooperation or can be substantially enhanced through it. They do not invest in horizontal coordination if the perceived gains in terms of influence are small or non-existent or the efforts required too great. 
Figure 3 here

\section{Conclusion}

The key element of strategies of interest representation of strong legislative regions tends to be their presence in the coordination of the member state position on EU policies. However, the there is great variation between member states in the formal rules governing this coordination process. Even within the group of federal or quasi-federal member states, the picture is one of diversity with regard to formal influence and requirements for horizontal coordination. As far as "cooperation" is concerned, the formal rules follow roughly the logic of their federal systems: Germany and Austria empower their regions as collective actors, while Belgium and the UK empower their regions individually, in line with the predominant dual separation of competences.

However, formal rules only show part of the picture, as the greatest part of the coordination process runs, in practice, through informal channels. The channels can be highly institutionalized as the working groups in Germany, or relatively ad hoc as coordination among experts in the UK, but in both cases substantive agreement is usually reached here. But the effect of informal practices creates diversity. Whereas the UK system produces low horizontal cooperation, the Belgian system produces high cooperation despite the fact that in both countries regions are empowered individually. Whereas the German system produces high cooperation in line with its formal rules and cooperative nature, cooperation in the Austrian system can be lower than expected when the option of a unified position does not exist. 
Overall, the hypothesis of the introductory article that Europeanization of intergovernmental relations leads to greater cooperation has to be treated with caution. The only country that sees a noticeable increase in the level of cooperation is Belgium (but only during specific periods of time). The cooperation effect in the UK is small. The German system uses the same channels that are used for domestic policy-making and the Austrian system arguably risks becoming less cooperative. The centralization hypothesis of the introductory article applies to three out of four countries, with the exception of Belgium where the central government is largely absent from informal cooperation.

On the other hand, the differences in the informal practices amongst both cooperative and dual states raise the question of the logic behind these practices. In this respect, it seems that formal rules do indeed matter. Through the extent to which they empower regions and the ways in which they empower regions, they create incentives or a lack of incentives to cooperate with other regions. In Belgium, the regions have so much influence over the national position that they cooperate closely to ensure that there will be a position. By contrast, in the UK and Austria, the lack of formal influence attributed to collective (or individual) positions means that there is no incentive to make the effort to coordinate. Thus the Europeanization of intergovernmental relations in practice is strongly shaped by the formal rules that are in place and that make certain types of adaptation more or less attractive. They can make regions work together, as in Belgium or Germany, or they can reinforce the tendency of regions to work as individuals, as in the UK. 


\section{Bibliography}

Aron M, (2006) 'EU Business: Reviews of Engagement with Europe and of EU Office', Report commissioned by the Scottish Executive.

Bache I. (2007), “Cohesion Policy”, in: P. Graziano, M. Vink (eds.), Europeanization: New Research Agendas, Basingstoke, Palgrave Macmillan, pp. 239-52.

Bache I. (2008): Europeanization and Multi-level Governance: Cohesion Policy in the European Union and Britain, Lanham/New York, Rowman and Littlefield.

Benz A., Eberlein B. (1999), “The Europeanization of regional policies: patterns of multilevel governance”, Journal of European Public Policy, Vol. 6(2), pp. 329-48.

Beyers, J., Delreux, T., \& Steensens, C. (2004). The Europeanisation of Intergovernmental Co-operation and Conflict Resolution in Belgium: The Case of Agriculture. In A. Bourne (Ed.), The EU and Territorial Conflict within Member States: Conflict or Co-operation? Leiden: Brill.

Beyers, Jan, \& Bursens, P. (2006). The European rescue of the federal state: How Europeanisation shapes the Belgian state. West European Politics, 29(5), 10571078. Routledge. Retrieved July 21, 2011, from http://www.tandfonline.com/doi/full/10.1080/01402380600968984.

Bomberg E., Peterson J. (2000), "Policy Transfer and Europeanization: Passing the Heineken Test?", Queen's Papers on Europeanization, No. 2/2000, 
http://www.qub.ac.uk/schools/SchoolofPoliticsInternationalStudiesandPhilosophy/Fi leStore/EuropeanisationFiles/Filetoupload,38445,en.pdf.

Börzel T. (1999), “Towards Convergence in Europe? Institutional Adaptation to Europeanisation in Germany and Spain”, Journal of Common Market Studies, Vol. 37(4), 573-596.

Börzel T., Risse T. (2000), “When Europe Hits Home: Europeanization and Domestic Change", European Integration Online Papers, Vol. 4(15), http://eiop.or.at/eiop/texte/2000-015a.htm.

Bulmer, S., Burch, M., Hogwood, P., \& Scott, A. (2006). UK Devolution and the European Union: A Tale of Co-operative Asymmetry. Publius, The Journal of Federalism, 36(1), 75-94.

Bundesrat, Beschluss, Entschließung des Bundesrates zur Novellierung der Badegewässer-Richtlinie 76/260/EWG, No. 49/02, 1/02/2002.

Bundesrat, Beschluss, Vorschlag für eine Richtlinie des Europäischen Parlaments und des Rates über die Qualität der Badegewässer KOM(2002) 581 endg., No. $857 / 02,14 / 02 / 2003$.

Bundesrat, Press Release, Bundesrat fordert praktikable und finanzierbare EUBadegewässer-Richtlinie, No. 19/2002, 01/02/2002. 
Bursens P., Deforche J. (2008), "Europeanization of Subnational Policies: the Impact of Domestic Factors on Regional Adaptation to European Integration”, Regional and Federal Studies, Vol. 18(1), pp. 1-18.

Bussjaeger, P., Bär, S., \& Willi, U. (2006). Kooperativer Föderalismus im Kontext der Europäischen Integration. Insbruck.

Bussjaeger, P., \& Djanani, A. (2009). Europapolitik und Europafähigkeit der Länder in Österreich. In K.-H. Lambertz \& M. Grosse Hüttmann (Eds.), Europapolitik und Europafähigkeit von Regionen (pp. 58-70). Baden-Baden: Nomos.

Cairney, P. (2006). Venue Shift Following Devolution: When Reserved Meets Devolved in Scotland. Regional and Federal Studies, 16(4), 429-446.

Caporaso J.A. (2007), “The Three Worlds of Regional Integration Theory”, in: P. Graziano, M. Vink (eds.), Europeanization: New Research Agendas, Basingstoke, Palgrave Macmillan.

Carter C. and McLeod A. (2005). The Scottish Parliament and the European Union: Analysing Regional Parliamentary Engagement. In: S. Weatherill and U. Bernitz (eds.), The Role of Regions and Subnational Actors in Europe. Oxford: Hart Publishing, pp. 67-88.

Conzelmann T. (1998), “'Europeanization’ of Regional Development Policies? Linking the Multi-Level Governance Approach with Theories of Policy Learning and Policy 
Change”, European Integration Online Papers, Vol. 2(4),

http://eiop.or.at/eiop/texte/1998-0004a.htm.

De Baere, Vademecum - onderhandelingen van Europese en multilaterale leefmilieudossiers en de rol van de piloten en de experten, versie DEF 29 January 2004, www.minaraad.be/hoorzittingen/hrz_2005/hoorzitting-vlaanderen-en-heteuropees-milieubeleid/de-organisatie-van-de-vlaamse-overheid-bij-deontwikkeling-van-het-europees-milieubeleid/vademecum-de-baere.pdf/download, accessed 10/07/2010.

Deforche, J. and Bursens, P. (2006), Europeanisering van Vlaanderen: enn evaluatie van de Vlaamse strategie in vijv Europese beleidscases, Rapport D/2006/10106/012, Bestuurlijke Organisatie Vlaanderen).

Hazell, R. (2000). Conclusion: The State and the Nations after One Year of Devolution. In R. Hazell (Ed.), The State and the Nations - The First Year of Devolution in the United Kingdom. Thorverton: Imprint Academic.

Högenauer A.L. (2011), Multi-level governance revisited: comparing the strategies of interest representation of legislative regions in EU environmental policy-making. $\mathrm{PhD}$ Thesis, University of Edinburgh, Edinburgh.

Högenauer A. (2012). Subnational Involvement in EU Policy-Making: The Case of Scottish Flood Risk Management. In H. Bruyninckx, S. Happpaerts, K. Van den Brande (eds.), Sustainable Development and Subnational Governments: Policy- 
Making and Multi-Level Interactions. Basingstoke: Palgrave Macmillan, pp. 198216.

Högenauer, A.L. (2013), All by Themselves? Legislative Regions and the Use of Unmediated Access to the European Level, European Political Science Review. doi:http://dx.doi.org/10.1017/S1755773913000180, 11 November 2013.

Jeffery, C. (2000). Sub-National Mobilization and European Integration: Does it Make any Difference? JCMS: Journal of Common Market Studies, 38(1), 1-23. doi: 10.1111/1468-5965.00206.

Kerremans, B., \& Beyers, J. (1997). The Belgian Sub-National Entities in the European Union: Second or Third Level Players? In C. Jeffery (Ed.), The Regional Dimension of the European Union - Towards a Third Level in Europe? London: Frank Cass.

Knodt M. (2000), “Europäisierung à la Sinatra: Deutsche Länder im europäischen Mehrebenensystem", in: M. Knodt, B. Kohler-Koch (eds.), Deutschland zwischen Europäisierung und Selbstbehauptung, Frankfurt, Campus Verlag, pp. 237-264.

Kovziridze, T. (2002). Europeanization of Federal Institutional Relationships:

Hierarchical and Interdependent Institutional Relationship Structures in Belgium, Germany and Austria. Regional and Federal Studies, 12(3), 128-155.

Ladrech R. (1994), "Europeanization of Domestic Politics and Institutions: The Case of France", Journal of Common Market Studies, Vol. 32(1), pp. 69-88. 
Laffin, M., Shaw, E., \& Taylor, G. (2007). The New Sub-National Politics of the British Labour Party. Party Politics, 13(1), 88-108.

Lambertz, K.-H., \& Foerster, S. (2009). Die belgischen Gemeinschaften und Regionen im europäsichen Rechtsetzungsprozess. In K.-H. Lambertz \& M. Grosse Hüttmann (Eds.), Europapolitik und Europafähigkeit von Regionen (pp. 21-24). Baden-Baden: Nomos.

Lynch, P. (2001). Scottish Government and Politics - An Introduction. Edinburgh: Edinburgh University Press.

MacPhail, E. (2008). Changing EU Governance: a New Opportunity for the Scottish Executive. Regional and Federal Studies, 18(1), 19-35.

Morass, M. (1997). Austria: The Case of a Federal Newcomer in European Union Politics. In C. Jeffery (Ed.), The Regional Dimension of the European UnionTowards a Third Level in Europe? London: Frank Cass.

Müller-Graff, P. C. (2005). The German Länder: Involvement in EC/EU Law and PolicyMaking. In S. Weatherill \& U. Bernitz (Eds.), The role of Regions and Sub-National Actors in Europe. Oxford: Hart Publishing.

Palmer R. (2004), "European Integration and Intra-State Relations in Germany and the United Kingdom”, in: A.K. Bourne (ed.), The EU and territorial politics within member states: conflict or cooperation?, Leiden, Brill. 
Radaelli, C. M. and Pasquier R. (2007), “Conceptual Issues”, in: P. Graziano, M. Vink (eds.), Europeanization: New Research Agendas, Basingstoke, Palgrave Macmillan, pp. 35-45.

Reid, C. T., \& Ruiz-Rico Ruiz, G. (2003). Scotland and Spain: The Division of Environmental Competencies. The International and Comparative Law Quarterly, 52(1), 209-225.

Risse T., Green Cowles M., Caporaso J. (2001), "Europeanization and Domestic Change: Introduction", in: M. Green Cowles, J. Caporaso, T. Risse, Transforming Europe: Europeanization and Domestic Change, Ithaca, Cornell University Press, pp. 1-20.

Schmidt V.A. (2006), Democracy in Europe. The EU and National Polities, Oxford, Oxford University Press.

Swenden, W. (2009). Schottland in Europa: Mit oder ohne Vereinigtes Königreich? In K.-H. Lambertz \& M. Große Hüttmann (Eds.), Europapolitik und Europafähigkeit von Regionen (pp. 101-122). Baden-Baden: Nomos.

Trench, A. (2008). Chapter 9: The Practice of Multi-Level Government: How Intergovernmental Relations Work in Federal Systems. In A. Trench (Ed.), The State of the Nations 2008. Exeter: Imprint Academic.Vereinbarung zwischen dem Bund und den Ländern gemäß Art. 15a B-VG über die Mitwirkungsrechte der Länder und Gemeinden in Angelegenheiten der europäischen Integration. (Austria).http://www.ris.bka.gv.at/GeltendeFassung.wxe?Abfrage=LrOO\&Gesetzes nummer=10000361, viewed 14/12/2012. 
www.lawa.de

www.umweltministerkonferenz.de

www.umweltministerkonferenz.de/arbeitsgremien.html

\section{Interviews}

Interview Amt der Kärntener Landesregierung, Abteilung 15, 30/03/2009.

Interview Amt der Vorarlberger Landesregierung, Abteilung für Europaangelegenheiten und Außenbeziehungen, 26/03/2009.

Interview Austrian Federal Ministry of Health, 3/04/2009.

Interview Belgian Permanent Representation, 27/05/2009.

Interview DGARNE, 20/05/2009.

Interview F Amt der Kärntener Landesregierung, Abteilung 18, 30/03/2009.

Interview F representative of the Bundesrat for flood risk management, 7/04/2009.

Interview F, VMM, 18/05/2009.

Interview former official of DEFRA, 7/07/2009.

Interview former official of the Water, Air, Soils and Flooding Division of the Scottish Government, 24/06/2009.

Interview Institut für Umwelt und Lebensmittelsicherheit des Landes Vorarlberg, 12/03/2009. 
Interview Liaison Office, 2/04/2009.

Interview Ministry of Social Affairs of Mecklenburg-West Pomerania, 18/03/2009.

Interview official (1), Federal Ministry of the Environment, Bonn, 20/03/2009.

Interview official (2), Federal Ministry of the Environment, Bonn, 20/03/2009.

Interview SEPA, 7/08/2009.

Interview VMM, 8/06/2009

Interview Water, Air, Soils and Flooding Division of the Scottish Government, 6/05/2009. 


\section{Figures}

Figure 1: Formal Aspects of Intergovernmental Relations in EU Affairs

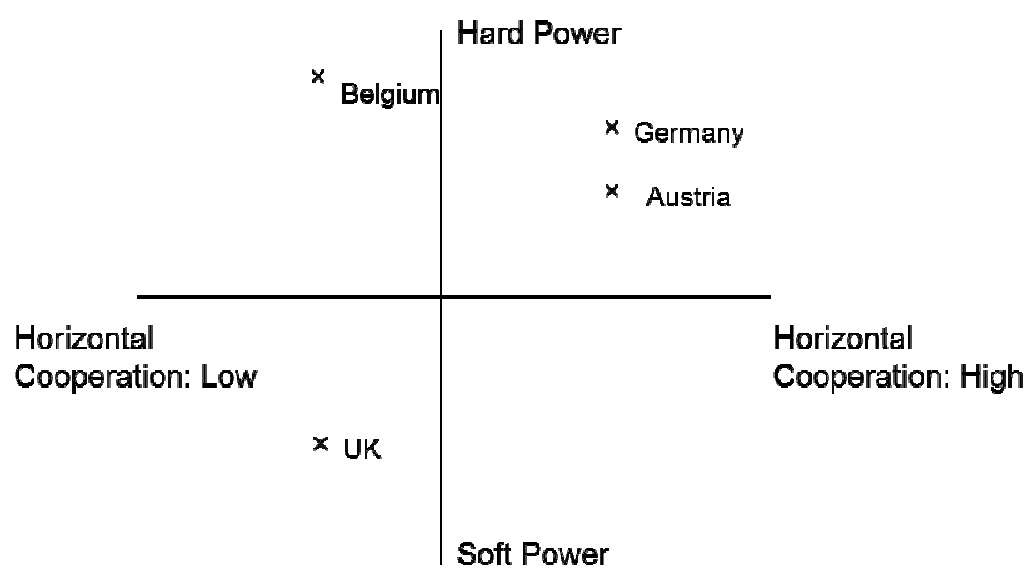

Hard power refers to a situation where regional governments are entitled to a certain amount of impact on the common position (e.g. veto rights). Soft power refers to the absence of guaranteed impact, e.g. when there is only an obligation to consult the regions.

Horizontal cooperation is defined as the amount (frequency of meetings/exchanges) of cooperation required between regions by formal rules before the national position is reached. 
Figure 2: The Impact of Informal Practices on Intergovernmental Cooperation

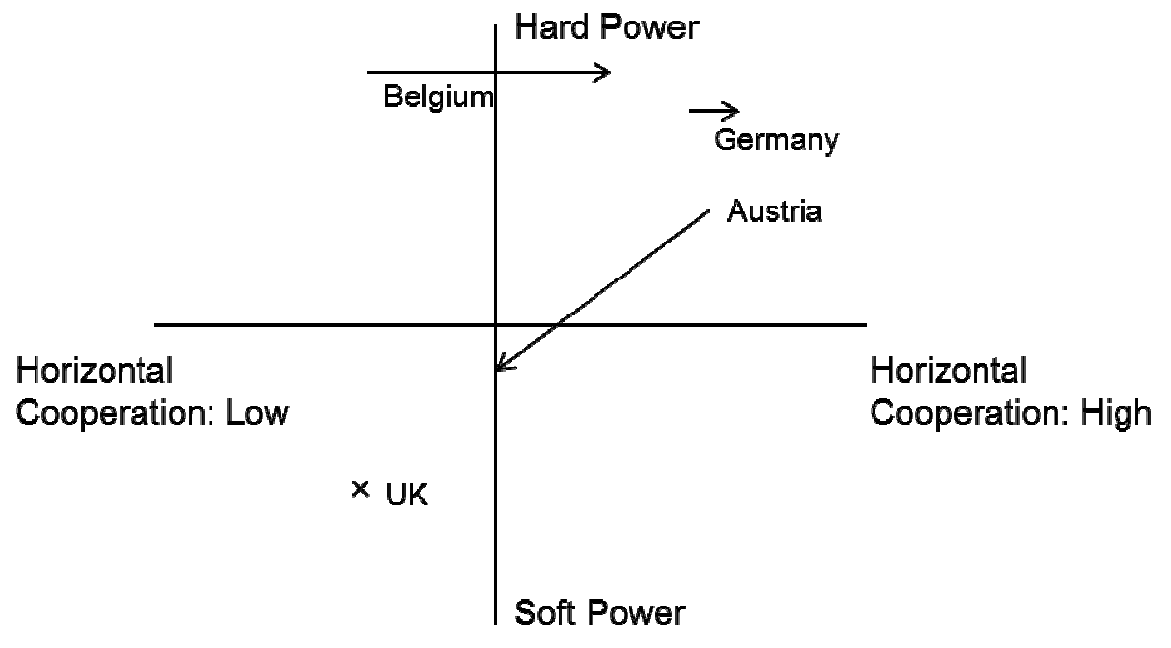

Unlike in Figure 1, horizontal cooperation refers to the actual amount of cooperation between regions. Similarly, soft and hard power are assessed on the basis of how much power regions can exercise in light of their actual behavior. 
Figure 3: Summary of Factors in the Emergence of Horizontal Cooperation

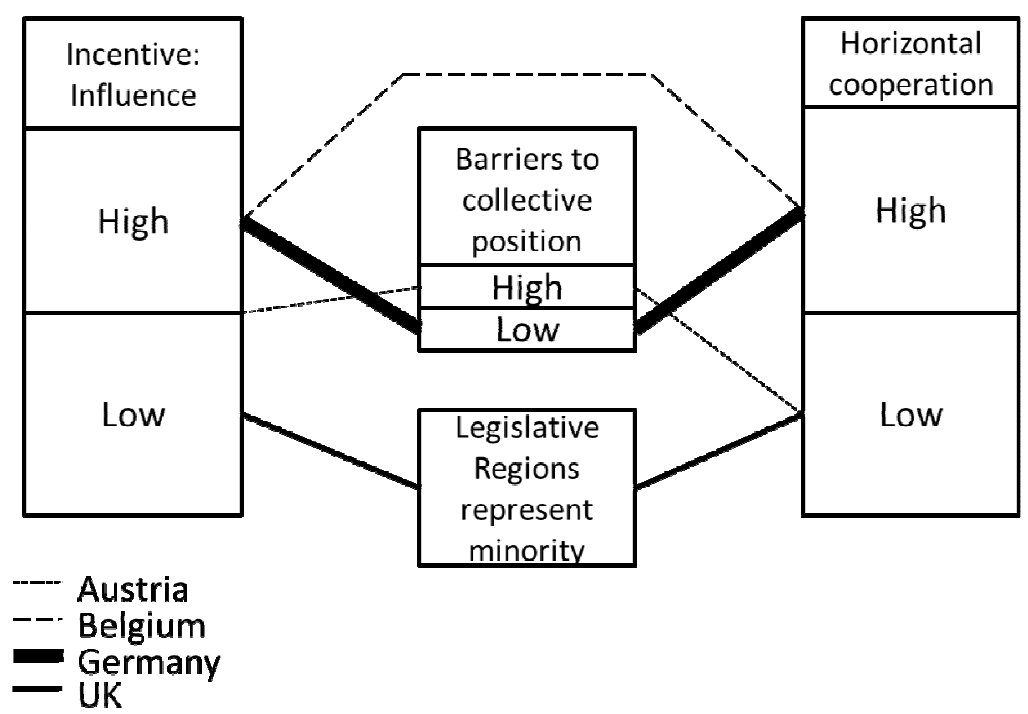

The main incentive to cooperate is formal power, which can only be exercised if there is a national position, whereby it does not matter if it is collective or individual regional influence. The second set of boxes represent the barriers to cooperation, for example high barriers for the attainment of a collective position where a collective position is required (e.g. unanimity requirements) or the fact that collective positions will still be minority positions (legislative regions in the UK).

\footnotetext{
${ }^{1}$ Austria is an exception here. The regions have few legislative powers, so that they are only affected in theri implementing powers.
} 